\title{
Evaluation of Genetic Variability for Quantitative and Qualitative Characters in Finger Millet (Eleusine coracana (L.) Gaertn.) Local Germplasm
}

\author{
Sneha R. Sapkal ${ }^{1}$, V.V. Bhavsar ${ }^{1 *}$ and K.K. Barhate ${ }^{2}$ \\ Department of Agricultural Botany, College of Agriculture Dhule-424 004 \\ (MPKV), (M.S.), India \\ *Corresponding author
}

\section{Keywords}

Finger millet, Genetic variability, Heritability, Genetic advance

Article Info

Accepted:

20 November 2018

Available Online:

10 December 2018
A B S T R A C T

A study was undertaken to determine the extent of genetic variability for grain yield and eight other quantitative characters and two qualitative characters in 40 genotypes of finger millet. The analysis of variance revealed significant differences among genotypes for all the characters. High genotypic coefficient and phenotypic coefficient of variation was recorded for grain iron content followed by grain yield per plant, number of tillers per plant, number of productive tillers per plant, main earhead length, number of fingers per earhead, grain calcium content, $100 \mathrm{ml}$ volume weight of grain. The lower magnitude of GCV was observed plant height, days to 50 per cent flowering and days to maturity. The high estimates of heritability in broad sense was observed for grain iron content followed by grain yield per plant, $100 \mathrm{ml}$ volume weight, main earhead length, number of tillers per plant, grain calcium content, number of fingers per earhead, days to 50 per cent flowering, days to maturity and plant height. Highest estimate of GA was noticed for grain calcium content. While, medium to low estimates of GA observed for $100 \mathrm{ml}$ volume weight, days to maturity, plant height, days to 50 per cent flowering, grain yield per plant, grain iron content, main earhead length, number of tillers per plant and number of productive tillers per plant. High heritability coupled with high genetic advance was recorded in grain yield per plant, $100 \mathrm{ml}$ volume, which indicated the predominance of additive gene effects. Improvement in these characters could be exercised by simple selection due to fixable additive gene effects.

\section{Introduction}

Millet is a collective term referring to a number of small seeded annuals grasses that are cultivated as grain crops, primarily on marginal lands in dry areas in temperate, subtropical and tropical regions. Finger millet, (Eleusine coracana), is also known as African millet, ragi, nachani, nagali. It is important staple food in parts of eastern and Central Africa and India. Finger millet is very adaptable to a wide range of environmental and climatic conditions, thrives at higher elevations than most other tropical cereals and tolerates salinity better than moist cereals. It is important cereal in Karnataka. It is intensively 
grown in Karnataka, Tamil Nadu, Andhra Pradesh, Orissa, Bihar, Gujarat, Maharashtra and in the hilly regions of Uttar Pradesh, Himachal Pradesh with a total area of 2.5 million hectares and 2.2 million tones of production.

Finger millet (Eleusine coracana (L.) Gaertn.), is one among highly utilized belong to family Poaceae and it ranks $4^{\text {th }}$ in the importance of world. Finger millet is originated from Ethiopia. It is allopolyploid with chromosome number $2 \mathrm{n}=4 \mathrm{x}=36$ and evolved from a cross between two diploid species Eleusine indica (AA) and Eleusine floccifolia or Eleusine tristachya (BB) as genome contributors (Hiremat and Salimath, 1992). Finger millet is mostly self pollinating with some amount of cross pollination (1\%) mediated by wind (Jansen and Ong 1996, Purseglove 1972).

In India, the total area under finger millet was 1.9 million hectares with production of 1.9 million tonne and productivity $1661 \mathrm{~kg} / \mathrm{ha}$ (2017). Out of these it is cultivated in Maharashtra is 966 ha and the production is 1008 tonne and productivity under Maharashtra state was $1043 \mathrm{~kg} / \mathrm{ha}$. (20142015).

Nutritive value of ragi per $100 \mathrm{~g}$ is Protein $7.3 \mathrm{~g}$, Fat $1.3 \mathrm{~g}$, Carbohydrate $72 \mathrm{~g}$, Calcium $3.44 \mathrm{~g}$, Iron $9.9 \mathrm{~g}$, Minerals $2.7 \mathrm{~g}$, Fibre $3.6 \mathrm{~g}$, Energy $328 \mathrm{kCal}$, Ash 2.6g, Vitamin A $6 \mathrm{RE}$, Thiamin $0.24 \mathrm{mg}$, Riboflavin $0.11 \mathrm{mg}$, Niacin $1.0 \mathrm{mg}$, Vitamin C $1 \mathrm{mg}$, Chloride $84 \mathrm{mg}$, Copper $0.5 \mathrm{mg}$, Iodine $10 \mu \mathrm{g}$, Magnesium 140 $\mathrm{mg}$, Manganese $1.9 \mathrm{mg}$, Molybdenum $2 \mu \mathrm{g}$, Phosphorous $250 \mathrm{mg}$, Potassium $314 \mathrm{mg}$. And essential amino acids are Cystine 1.7, Isoleucine 4.0, Leucine 7.8, Lysine 2.5, Methionine 5.0, Phenylalanine 4.1, Tryptophan 1.3, Threonine 4.1, Tyrosine 4.1, Valine 6.4. This is versatile grain that can probably be used in dozens of types of foods, including many that are quite unlike its traditional ones. Its several major uses are porridge, bread, malt, beverage, fodder, popped Products.

\section{Materials and Methods}

The experimental materials consisting forty germplasm of finger millet collected from Nashik, Dhule, Ahmednagar, Satara Pune, Jalgaon and Nandurbar districts of Maharashtra (Table 2). The experiment was laid out in RBD with three replications at Department of Botany, College of Agriculture, Dhule (M.S.) during Kharif 2017. By adopting a spacing of $22.5 \mathrm{~cm}$ between rows and $10 \mathrm{~cm}$ between plants respectively, at recommended package of practices were followed to raise good and healthy crop stand. Data were collected on eleven yield and yield contributing characters viz., days to 50\% flowering, days tp maturity, plant height, number of tillers per plant, number of productive tillers per plant, main earhead length, number of fingers per earhead, $100 \mathrm{ml}$ volume weight, grain yield per plant, grain iron content, grain calcium content.

The mean of five plants was subjected to statistical analysis. The data for different characters were statistically analyzed for significance by using analysis of variance technique described by Panse and Sukhatme (1985).The adapted design was Randomized Block Design (RBD) with three replications. The significance of mean sum of square for each character was tested against the corresponding error degrees of freedom using "F" Test (Fisher and Yates, 1967).The components of variances were used to estimate genetic parameters like phenotypic and genotypic coefficient of variation (PCV and GCV) as per the formula given by Burton and De Vane (1953). Heritability in broad sense was calculated according to the formula given by Allard (1960) and expressed in 
percentage. Genetic advance was estimated by using Burton (1953). Statistical analysis was done by using WINDOSTAT program.

\section{Results and Discussion}

Analysis of variance revealed significant differences among genotypes for all the characters. Studies of genetic variability exhibited high phenotypic and genotypic coefficients of variation, heritability and genetic advance as percent of mean for the traits viz., Genetic advance as a per cent of mean was observed highest for grain iron content followed by grain yield per plant. Whereas, it was found medium for number of tillers per plant, number of productive tillers per plant, main earhead length, number of fingers per earhead, $100 \mathrm{ml}$ volume weight, grain calcium content while low estimates of GA observed for plant height, days to 50 per cent flowering and days to maturity indicating simple selection can be practiced for improvement of these characters (Table 1). It shows that the presence of variability and choice of material is appropriate.

Improvement of economic characters like yield through selection is conditioned by the nature and magnitude of variability existing in such populations. However, the phenotypic expression of complex character like yield is a combination of genotype, environment and their interaction. This indicates the need for partition of overall variability into heritable and non-heritable components with the help of appropriate statistical techniques.

Possibility of achieving improvement in any crop plants depends largely on the magnitude of genetic variability. Phenotypic variability expressed by a genotype or a group of genotypes in any species can be partitioned into genotypic and environmental components. The genotypic component being the heritable part of the total variability, its magnitude for yield and its component characters influence the selection strategies to be adopted by the breeders

Coefficients of variation studies indicated that the estimates of PCV were slightly higher than the corresponding GCV estimates for all the characters, indicating that the characters were less influenced by the environment. Therefore, selection for the improvement of these traits.

Table.1 Analysis of variance for eleven characters in finger millet

\begin{tabular}{|c|c|c|c|c|}
\hline \multirow{2}{*}{$\begin{array}{l}\text { Sr. } \\
\text { No }\end{array}$} & \multirow[b]{2}{*}{ Characters } & \multicolumn{3}{|c|}{ Mean sum of square } \\
\hline & & Replication & Genotype & Error \\
\hline 1 & Days to $50 \%$ flowering & 33.908 & $279.59 * *$ & 16.429 \\
\hline 2 & Days to maturity & 33.033 & $393.21 * *$ & 35.272 \\
\hline 3 & Plant height $(\mathrm{cm})$ & 41.308 & $415.080 * *$ & 45.445 \\
\hline 4 & No. of tillers / plant & 0.582 & $7.679 * *$ & 0.308 \\
\hline 5 & No. of productive tillers / plant & 0.410 & $6.308 * *$ & 0.210 \\
\hline 6 & Main earhead length $(\mathrm{cm})$ & 0.290 & $11.546 * *$ & 0.272 \\
\hline 7 & No. of fingers / earhead & 0.614 & $6.986 * *$ & 0.374 \\
\hline 8 & $100 \mathrm{ml}$ volume weight (gm) & 16.808 & $662.402 * *$ & 14.859 \\
\hline 9 & Grain yield / plant (gm) & 8.258 & $210.99 * *$ & 4.053 \\
\hline 10 & Grain iron content $(\mathrm{mg} / 100 \mathrm{gm})$ & 0.069 & $19.561 * *$ & 0.069 \\
\hline 11 & Grain calcium content $(\mathrm{mg} / 100 \mathrm{gm})$ & 1210.40 & $11756.44 * *$ & 554.75 \\
\hline
\end{tabular}


Table.2 List of finger millet genotypes with origin

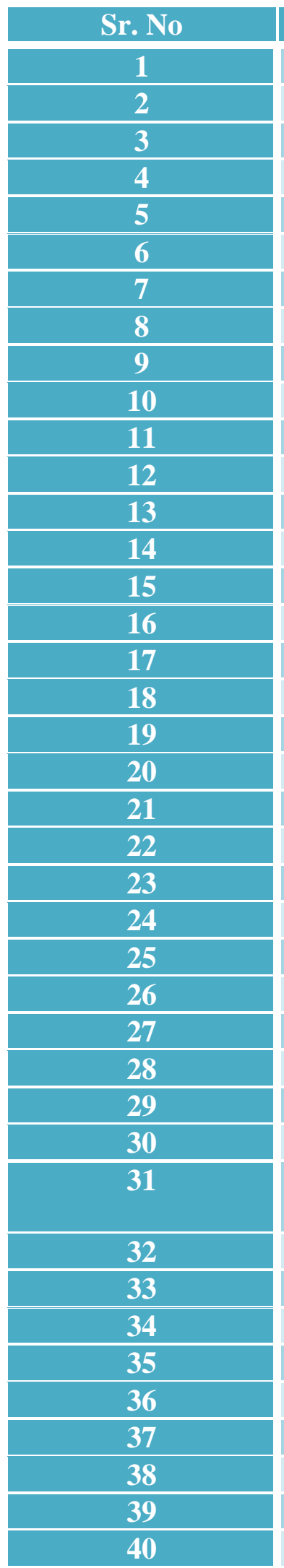

\begin{tabular}{|c|c|}
\hline Genotypes & Source \\
\hline DHFM-01 & Sinner (Nashik) \\
\hline DHFM-02 & Niphad (Nashik) \\
\hline DHFM-03 & Niphad (Nashik) \\
\hline DHFM-04 & Niphad (Nashik) \\
\hline DHFM-05 & Surgana (Nashik) \\
\hline DHFM-06 & Igatpuri (Nashik) \\
\hline DHFM-07 & Niphad (Nashik) \\
\hline DHFM-08 & Niphad (Nashik) \\
\hline DHFM-09 & Sinner (Nashik) \\
\hline DHFM-10 & Niphad (Nashik) \\
\hline DHFM-11 & Surgana (Nashik) \\
\hline DHFM-12 & Sakri (Dhule) \\
\hline DHFM-13 & Akole (Ahmednagar) \\
\hline DHFM-14 & Newasa (Ahmednagar) \\
\hline DHFM-15 & Akole (Ahmednagar) \\
\hline DHFM-16 & Akole (Ahmednagar) \\
\hline DHFM-17 & Satara (Satara) \\
\hline DHFM-18 & Bhor (Pune) \\
\hline DHFM-19 & Shirpur (Pune) \\
\hline DHFM-20 & Shirpur (Pune) \\
\hline DHFM-21 & Junnar (Pune) \\
\hline DHFM-22 & Junnar (Pune) \\
\hline DHFM-23 & Shirpur (Pune) \\
\hline DHFM-24 & Peth (Nashik) \\
\hline DHFM-25 & Jalgaon (Jalgaon) \\
\hline DHFM-26 & Sinner (Nashik) \\
\hline DHFM-27 & Nashik (Nashik) \\
\hline DHFM-28 & Nandurbar (Nandurbar) \\
\hline DHFM-29 & Nandurbar (Nandurbar) \\
\hline DHFM-30 & Nandurbar (Nandurbar) \\
\hline DHFM-31 & Kolhapur \\
\hline DHFle Nachani) & Akole (Ahmednagar) \\
\hline DHFM-33 & Akorbar (Nandurbar) \\
\hline DHFM-34 & Akole (Ahmednagar) \\
\hline DHFM-35 & Akole (Ahmednagar) \\
\hline DHFM-36 & Akole (Ahmednagar) \\
\hline DHFM-37 & Akole (Ahmednagar) \\
\hline DHFM-38 & Akole (Ahmednagar) \\
\hline DHFM-40 & Akole (Ahmednagar) \\
\hline & Akor \\
\hline & \\
\hline & \\
\hline & \\
\hline & \\
\hline
\end{tabular}




\section{Int.J.Curr.Microbiol.App.Sci (2018) 7(12): 2938-2945}

Table.3 Parameters of genetic variability for different characters in finger millet

\begin{tabular}{|c|c|c|c|c|c|c|c|c|c|c|c|}
\hline $\begin{array}{l}\text { Sr. } \\
\text { No }\end{array}$ & Characters & $\begin{array}{c}\text { General } \\
\text { Mean }\end{array}$ & $\sigma^{2} g$ & $\sigma^{2} p$ & $\sigma^{2} \mathrm{e}$ & $\begin{array}{c}\mathrm{GCV} \\
(\%)\end{array}$ & $\begin{array}{c}\text { PCV } \\
(\%)\end{array}$ & $\begin{array}{l}\mathrm{ECV} \\
(\%)\end{array}$ & $\begin{array}{c}\mathrm{h}^{2} \\
(\mathrm{BS} \%)\end{array}$ & GA & $\begin{array}{c}\mathrm{GA} \text { as } \% \\
\text { of mean }\end{array}$ \\
\hline 1 & Days to 50 per cent flowering & 93.43 & 87.72 & 104.15 & 16.42 & 10.02 & 10.92 & 4.33 & 84.23 & 17.70 & 18.95 \\
\hline 2 & Days to maturity & 134.04 & 119.31 & 154.58 & 35.27 & 8.14 & 9.27 & 4.43 & 77.18 & 19.76 & 14.74 \\
\hline 3 & Plant height (cm) & 102.23 & 123.21 & 168.65 & 45.44 & 10.85 & 12.70 & 6.59 & 73.05 & 19.54 & 19.11 \\
\hline 4 & No. of tillers/plant & 5.60 & 2.45 & 2.76 & 0.30 & 27.95 & 29.66 & 9.91 & 88.83 & 3.04 & 54.27 \\
\hline 5 & No. of productive tillers/plant & 5.17 & 2.03 & 2.24 & 0.21 & 27.57 & 28.96 & 8.87 & 90.61 & 2.79 & 54.06 \\
\hline 6 & Main earhead length $(\mathrm{cm})$ & 8.78 & 3.75 & 4.03 & 0.27 & 22.06 & 22.84 & 5.94 & 93.24 & 3.85 & 43.88 \\
\hline 7 & No. of fingers/ earhead & 7.03 & 2.20 & 2.57 & 0.37 & 21.10 & 22.82 & 8.69 & 85.48 & 2.82 & 40.18 \\
\hline 8 & $100 \mathrm{ml}$ volume weight & 76.78 & 215.84 & 230.70 & 14.85 & 19.13 & 19.78 & 5.02 & 93.56 & 29.27 & 38.12 \\
\hline 9 & Grain yield/plant (gm) & 20.16 & 68.98 & 73.03 & 4.05 & 41.18 & 42.37 & 9.98 & 94.45 & 16.62 & 82.44 \\
\hline $\begin{array}{l}1 \\
0\end{array}$ & $\begin{array}{l}\text { Grain iron content }(\mathrm{mg} / 100 \\
\mathrm{gm})\end{array}$ & 4.65 & 6.49 & 6.56 & 0.06 & 54.71 & 55.00 & 5.64 & 98.95 & 5.22 & 112.12 \\
\hline $\begin{array}{l}1 \\
1\end{array}$ & $\begin{array}{l}\text { Grain calcium content } \\
(\mathrm{mg} / 100 \mathrm{gm})\end{array}$ & 308.05 & 3733.89 & 4288.64 & 554.75 & 19.83 & 21.25 & 7.64 & 87.06 & 117.45 & 38.12 \\
\hline
\end{tabular}


The difference between GCV and PCV values was more for grain calcium content, plant height indicating that selection based on phenotypic observation may not be very effective for these traits (Table 3). The GCV and PCV were high for number of tillers per plant, number of productive tillers per plant, main earhead length, number of fingers per earhead and grain yield per plant showing greater scope for selection for improvement of these characters. Similar results obtained to John et al., (2006), Bedis et al., (2006), Priyadharshini et al., (2011), Lule et al., (2012), Reddy et al., (2013), Karad et al., (2013 Wolie et al., (2013), Suryanarayana et al., (2014) Jyosthana et al., (2016), and Mahanthesha et al., (2017), Suryanarayana et al., (2014) and Mahanthesha et al., (2017).

High heritability coupled with high genetic advance reveals the presence of lesser environmental influence and prevalence of additive gene action in their expression (Panse, 1957). Lower values of genetic advance indicate the prevalence of narrow range of variability, high $\mathrm{G} X \mathrm{E}$ interaction (non-additive gene action). In the present investigation high heritability coupled with high genetic advance as per cent of mean was observed for grain iron content, grain yield per plant, number of productive tillers per plant and main earhead length suggesting that these characters are govern by additive genes and phenotypic selection for these characters may be effective.

Previously similar results were reported by Ganapathy et al., (2007). Prabhu et al., (2008) Karad et al., (2013). Auti et al., (2017). High heritability with low genetic advance or low heritability with low genetic advance is observed for any given character, presence of non additive gene action may be suspected.

High heritability with low genetic advance was observed for number of pods per cluster,
100 seed weight, pod length and number of seeds per pod. This indicates non-additive gene action and selection in early genotypes for such traits may not be effective.

Genotypic coefficient of variation (GCV) along with heritable estimates would provide a better picture of the amount of genetic advance to be expected by phenotypic selection (Burton, 1953). It is suggested that genetic gain should be considered in conjunction with heritability estimates (Johnson et al., 1955). Heritability estimates along with genetic advance are normally more helpful in predicting the gain under selection than heritability estimates alone (Table 3 ).

In conclusion, the material chosen differed in their genotypic make up as evidenced by the significant differences among them in respect of all the quantitative characters studied. Phenotypic coefficients of variations estimate were slightly higher than the genotypic coefficients of variation for all the trait, indicating low environmental influence on the expression of all the traits.

\section{References}

Allard, R. W. 1961. Relationship between genetic diversity and consistency of performance in different environments. Crop Sci. 1: 127-133

Agalodia, A. V., Desai, K. B. and Tikka, S. B. S. 1979. Analysis of parameters of variability and relationship of yield attributes in finger millet. Indian $J$. Agric. Sci., 49(12): 924-928.

Auti, S. G., Kazi, T. and Ahire, D. D. 2017. Morpho- agronomic diversity in [Eleusine coracana (L.) Gaertn.] landraces from Maharashtra State (India). J. Sci. Agric., 1: 54-61.

Bedis, M. R., Patil, H. S., Jangle, G. D. and Patil, V. S. 2006. Correlation and Path analysis in finger millet [Eleusine 
coracana (L.) Gaertn.]. Crop. Res., 31: 264-266.

Burton, G. W. and E. H.Devene 1953. Estimating heritability in tall fescue (Festeca arundina Ceae) from replicated clonal material. Agron. J. 45: 478-481.

Dawa, C. L., Plana, P. and Sharma, S. K. 1996. Studies on genetic variability and component analysis in ragi [Eleusine coracana (L.) Gaertn.]. Indian J. Genet., 56: 162-168

Dhamdhere, D. H., Pandey, P. K. and Shrotria, P. K. 2011. Genetic variability, heritability and genetic advance of yield components and mineral nutrients in finger millet [Eleusine coracana $(L$. Gaertn.]. Pantnagar J. Res., 9: 46-48.

Ganapathy, S., Nirmalakumari, A., Senthil, N., Devan, P., Muthiah, A. R., Raveendran, T. S. 2007. Variability studies in recombinant inbred lines of finger millet [Eleusine coracana $(L$. Gaertn.]. Res.-on-Crop., 8(3): 795-796.

Fisher, R.A. and Yates. 1967. Statistical Tables for Biological Agricultural and Medical Research Oliver and Boyd, Edington.

Gowda, M. 1996. Genetic variability studies on African germplasm of finger millet [Eleusine coracana (L.) Gaertn.]. M. Sc. (Agri.) Thesis, Uni. Agril. Sci., Bangalore, India.

Haider, Z. A., Mahto, J. L., Kumar, B. and Ganguly, D. K. 1995. Genetic variability in finger millet. J. Res. (BAU), 7(1): 43-47.

Hiremat, S.C. and Salimat S. S. 1992. The "A" genome donor of Eleusine coracana (L.) Gaertn. (Gramineae). Theoret. Appl. Genet. 84(5-6): 747-754.

Jansen, P. M. C. and Ong, H. C. 1996. Eleusine coracana (L.) Gaertner ev. group Finge Millet. Plant Resources of South-East Asia No 10. Cereals, Backhuys Publishers, Leiden,
Netherlands. Pp.90-95.

Jawale, L. N., Bhave, S. G., Deosarkar, D. B., Jadhav, R. A. and Choudhari, A. K. 2017. Studies on heritability, genetic advance for grain yield and component traits in finger millet [Eleusine coracana (L.) Gaertn.]. J. Genet. Genomics \& Plant Breeding, 1(1): 4953.

John, K. 2006. Variability and Correlation Studies in Quantitative traits of Finger Millet [Eleusine coracana Gaertn]. Agril. Sci. Digest., 26: 166-169.

Johnson, H. W., H. F. Robinson and R. E. Comstock. 1955. Estimation of genetic and environmental variability in soybeans. Agron. J., 47: 314-318.

Johnson, H. W., Robinson, H. F. and Comstock, R. E.1955a. Estimates of genetic and environmental variability in Soybeans. Agron. J., 47: 314-318.

Karad, S. R. and Patil J. V. 2013. Assessement of Genetic Diversity Among Finger Millet [Eluesine coracana (L.) Gaertn.]. Genotype. Int. J. Int. Sci. Inn. Tech. Sec. C, 2(4): 37-43

Lule, D., Tesfaye, K., Fetene, M. and Santie De Villiers. 2012. Inheritance and Association of Quantitative Traits in Finger Millet [Eleusine coracana (L.) Gaertn.] Landraces Collected from Eastern and South Eastern Africa. Int. J. Genet., 2(2): 12-21.

Mahanthesha, M., Sujatha, M., Meena, A. K. and Pandravada S. R. 2017. Studies on Variability, Heritability and Genetic Advance for Quantitative Characters in Finger millet [Eleusine coracana (L.) Gaertn.] Germplasm. Int. J. Curr. Microbiol. App. Sci., 6(6): 970-974.

Mishra, H. P., Patnaik, M. C. and Nayak, B. K., 1980a Variation in quantitative traits in finger millet. Indian J. agril. Sci., 50: 298-301.

Panse, V. G. and P. V. Sukhatme. 1985. Statistical methods for agricultural 
workers. ICAR, New Delhi. $4^{\text {th }}$ Edition, pp. 97-156.

Purseglove J. W. 1972. Tropical crops: Monocotyledons. Molecular Nutrition and Food Research. 19(5-6): 395-524

Prabhu, D. A., Selvi, B. and Govindaraj, M. 2008. Genetic variability and multivariate analysis in finger millet [Eleusine coracana (L.) Gartn.]. Crop. Res., 36:1/3, 218-223.

Priyadharshani, C., Nirmalkumari, A., John Joel, A. and Raveendran, $\quad$ A. 2011. Genetic Variability and Trait Relationships in Finger Millet [Eleusine coracana (L.) Gartn.] Hybrids. Madras Agril. J., 98: 18-21.

Ramakrishna, M. B., Gowda, B. T. S., Katti, M., Seetharam, A., Mantur, S. G., VIswanath, S., Channamma, K. A. L., Krishnappa, M., Vasanth, K. R., Krishnamurthi, B. and Jagadeeswara, K. 1996. Evaluation of finger millet germplasm. Germplasm Catalogue 1. Small Millets Project Co-ordination Unit, UAS-KAR, Bangalore. 33-35.

Reddy,C. V. C. M., PVRM Reddy, Munirathnam, P. and Gowda, J. 2013. Studies of genetic variability in yield and yield attributing traits of finger millet [Eleusine coracana (L.) Gaertn.]. Indian J. Agric. Res., 47(6): 549 - 552.

Satish, D., Shanthakumar, G., Salimath, P. M., Prasad, S. G. 2007a. Studies on genetic variability for productivity traits in finger millet. Int. J. Plant Sci., Muzaffarnagar. 2(2): 19-22.

Suryanarayana, L., Sekhar, D. and Venugopala Rao N. 2014. Genetic Variability and Divergence Studies in Finger Millet [Eleusine coracana (L.) Gaertn.]. Int. J. Curr. Microbiol. App. Sci., 3(4): 931-936.

Solomon Igosangwa Shibairo, Oliver Nyongesa, Richard Onwonga and Jane Ambuko. 2014. Variation of Nutritional and Anti-Nutritional Contents in Finger Millet [Eleusine coracana (L.) Gaertn.] Genotypes. IOSR J. Agril. and Veterinary Sci., (IOSR-JAVS) 7(11): 06-12.

Wolie, A., Dessalegn, T. and Belete, K. 2013. Heritability, variance components and genetic advance of some yield and yield related traits in Ethiopian collections of finger millet [Eleusine coracana $(L$.) Gaertn.] genotypes. African J. Biotech. 12(36): 5529-5534.

\section{How to cite this article:}

Sneha R. Sapkal, V.V. Bhavsar and Barhate, K.K. 2018. Evaluation of Genetic Variability for Quantitative and Qualitative Characters in Finger Millet (Eleusine coracana (L.) Gaertn.) Local Germplasm. Int.J.Curr.Microbiol.App.Sci. 7(12): 2938-2945.

doi: https://doi.org/10.20546/ijcmas.2018.712.335 